\title{
Fire activity and burned forest lands decreased during the last three decades in Spain
}

\author{
Itziar R. Urbieta ${ }^{1}$ (I) $\cdot$ Magí Franquesa $^{1,2} \cdot$ Olga Viedma $^{1} \cdot$ José M. Moreno $^{1}$
}

Received: 26 May 2019 / Accepted: 7 August 2019 / Published online: 27 August 2019

(C) INRA and Springer-Verlag France SAS, part of Springer Nature 2019

\begin{abstract} determine how fire activity is responding to such changes. changes in climate, land-use and land-cover, and fire suppression. 1980-2013 in Spain at country and provincial levels. artificial areas all increased. Spain during the last 34 years.

Handling Editor: Paulo Fernandes

Contributions of the co-authors Conceptualization: JMM, IRU, and OV; Methodology: IRU, MF, OV, and JMM; Formal analysis: IRU, $\mathrm{MF}$, and $\mathrm{OV}$; Investigation: IRU, MF, OV, and JMM; Writing - original draft: IRU and JMM; Writing, review, and editing: IRU, MF, OV, and JMM; Project Administration: JMM; Funding acquisition: JMM. All authors reviewed and agreed on the final manuscript.
\end{abstract}

- Key message Fire activity has decreased in the last decades in Spain as a whole and in most provinces. However, fire risk factors have increased. Wildfires are burning preferentially treeless areas. Flammable pine areas burn less, while the less flammable oak forests burn more. This decreasing fire activity coincides with increasing fire suppression resources.

- Context Climate and other fire risk factors are changing across the world, including the Mediterranean region. It is important to

- Aims To identify spatio-temporal changes in fire frequency and size, main tree species burned, and their association with

- Methods Analysis of trends, breakpoints, and association among the time series of fire variables and fire risk factors during

- Results Wildfires in Spain have been decreasing in number, burned area, mean, and largest fire sizes. Fires are more frequently burning treeless areas than forests. Pine forests are burning less, while oak forests are burning more. Fire suppression resources, particularly aerial ones, increased significantly. Risk factors like the mean summer fire weather index, and the forested and the

- Conclusion Despite increasing fire risk factors, wildfires have decreased at the country as a whole and in most provinces in

Keywords Climate change $\cdot$ Fire risk $\cdot$ Fire suppression $\cdot$ Fire weather $\cdot$ Land-use and land-cover change

Itziar R. Urbieta

itziar.rodriguez@uclm.es

José M. Moreno

josem.moreno@uclm.es

Magí Franquesa

magifranquesa@gmail.com

Olga Viedma

olga.viedma@uclm.es
Department of Environmental Sciences, University of Castilla-La Mancha, Avenida de Carlos III s/n, E-45071 Toledo, Spain

2 Present address: Department of Geology, Geography, and Environmental Sciences, University of Alcalá, Colegios 2, 28801 Alcalá de Henares, Spain 


\section{Introduction}

Climate and weather exert major controls on wildfire occurrence, but human factors have influenced fire regimes in different ecosystems across the world (Pausas and Keeley 2009; Bowman et al. 2017). Seasonal fire patterns have been altered due to human pressure (e.g., Benali et al. 2017), often overriding the effect of weather/climate (e.g., Syphard et al. 2017), by modifying ignitions (e.g., Parisien et al. 2016), fuel types and structure (e.g., Andela et al. 2017), and through fire suppression (e.g., Brotons et al. 2013).

In southern Mediterranean European Union countries (EUMed), the economy of the region has been remarkably transformed in the last half century, with the consequent changes in rural population, land management, and other socioeconomic factors, which have affected fire patterns (e.g., Moreno et al. 1998; Pausas and Fernández-Muñoz 2012). The former land-use mosaic and low fuel load were first disrupted by forest expansion and agriculture decline due to rural abandonment (e.g., Moreira et al. 2001; Viedma et al. 2015). Afforestation programs contributed to increase fuel connectivity and accumulation (e.g., Fernandes et al. 2010; Iriarte-Goñi and Ayuda 2018), shifting the fire regime towards higher burned area, particularly during the 1970s-1980s (e.g., Moreno et al. 2014; Fernandes et al. 2014). Nonetheless, in the last decades, urban development and greater investment in fire suppression have modified spatial and temporal fire incidence (Turco et al. 2014; Fréjaville and Curt 2017).

Recent studies at coarse scales showed that fires have been overall decreasing at EUMed (e.g., Urbieta et al. 2015; Turco et al. 2016), consistent with decreasing patterns found globally (e.g., Andela et al. 2017; Earl and Simmonds 2018). These reduced fire activity has been reported in spite of increasing drought (Gudmundsson et al. 2014; Turco et al. 2017), and more severe fire weather (Venäläinen et al. 2014; Jolly et al. 2015). However, we argue that large-scale fire statistics (i.e., global level, country level) might be misleading; fire incidence might be globally decreasing but in some areas, it might be doing the opposite. For example, increased fire activity has been reported for some areas within EUMed, when the scale of analysis varied from countries to regions and provinces (e.g., Rodrigues et al. 2013; Urbieta et al. 2015), municipalities (e.g., Nunes et al. 2016), or grid-cell level (e.g., Silva et al. 2019), particularly for the number of fires, and mostly due to the contribution of small fires (e.g., Rodrigues et al. 2013; Viedma et al. 2018). Fire activity may be declining but not for all fire sizes. Although the number of large fires in the Mediterranean region has exhibited a decline in the last decades (San-Miguel-Ayanz et al. 2013), there are years with large and catastrophic fires, the last being in Portugal in 2017 (Gómez-González et al. 2018). This implies that maximum fire size can still be large under extreme weather conditions, despite the efforts made in suppression, which may have contributed to the decline of total burned areas (Ruffault and Mouillot 2015).

The spatial distribution of woodland types and structures can determine fire probability (Vázquez et al. 2015; Nunes et al. 2019). However, most studies on fire trends have disregarded what fires burned. Ignitions are not evenly distributed in the landscape (Ganteaume et al. 2013); thus, the spatial variability of fires, and the corresponding vegetation they burn, may change due to alterations in ignition patterns. It is unclear how changes in fire trends are affecting the various dominant forest types in the region. Improved understanding of how fire incidence is spatially changing and whether fires are differentially affecting forest lands is required to address future management needs in a context of more severe fire weather (Bedia et al. 2014; Turco et al. 2018).

Here we analyzed the trends in fire activity, fire risk factors, and firefighting resources at two spatial scales (country and provincial level), during 1980-2013 in Spain. Specifically, we investigated spatio-temporal changes in trends and breakpoints for the time series of the number of fires, burned area, and fire size, as well as the type of burned area (treed and treeless) and main tree species. Furthermore, we explored the relationships of observed fire trends with fire risk factors (fire weather, land-use and land-cover [LULC] changes), and fire suppression resources.

\section{Materials and methods}

\subsection{Data}

We used the Spanish National Forest Fire Statistics (EGIF) of the Spanish Ministry of Agriculture, Fisheries and Food, which contains records of all fires at a $10 \times 10 \mathrm{~km}$ resolution in a UTM grid. Each record contains information about the fire itself (e.g., fire type, size [total burned area (ha)], type of forest burned area (ha) [i.e., treed or treeless], and the burned area (ha) of the main forest tree species). Additionally, the resources used to contain each fire are recorded, including the type and number of terrestrial and aerial means.

We selected all fires $>1$ ha occurred in Peninsular Spain and the Balearic Islands from 1980 to 2013 (194657 fires). Earlier data (since 1968) were discarded to ensure maximum homogeneity of the fire database across all administrative units. Missing fire records were detected in many provinces before 1980, and firefighting resources were not reported. Three provinces in the north (Álava, Vizcaya, and Navarra) were not included due to the lack of data for the complete period. We grouped fire records at two spatial scales: whole country and 45 provinces. Then, we calculated annually the total number of fires $(>1 \mathrm{ha}$ ), the total burned area (ha) by all fires 
(>1 ha), and the median (percentile 50th, $\mathrm{P}_{50}$ ) and largest (percentile 95th, $\mathrm{P}_{95}$ ) fire size (ha). For the forest burned area, we aggregated the hectares burned for treed (i.e., tree-covered) and treeless areas (i.e., covered by shrubs or herbs), expressed in hectares and in percentage per year. Moreover, we calculated burned area per year (ha) for each tree species (52 species). Nonetheless, we focused on the most abundant tree species of the genera Pinus (P. halepensis Mill., P. pinaster Aiton, P. pinea L., P. radiata D.Don, P. nigra Aiton, P. sylvestris L.) and Quercus (Q. ilex L., Q. suber L., Q. faginea Lam., $Q$. pyrenaica Will., Q. robur L., Q. petraea [Matt.] Liebl.).

Additionally, we calculated changes in fire risk factors at the whole country and for each province, including Fire Weather Index (FWI) of the Canadian system (van Wagner 1987), and main LULC changes. For FWI, we calculated annually the mean FWI of the extended summer months (Juneto-September, JJAS), and the 95 th percentile $\left(\mathrm{P}_{95} \mathrm{FWI}\right)$, based on daily meteorological data provided by the reanalysis of WFDEI (WATCH-Forcing-Data-ERA-Interim) (Weedon et al. 2014). For LULC changes, we used the European CORINE Land Cover maps of 1987 (CLC90), 2000 (CLC00), and 2012 (CLC12), which included a hierarchical nomenclature in three levels (Heymann et al. 1994). For the first level, we calculated the percentage of change in the area of the main classes of forest, and agricultural and artificial LULC types. For the second and third levels, we focused on changes in forest area between maps including forests, i.e., treed (conifer, broad-leaved, and mixed), and treeless (shrubs and herbs) LULC types. Finally, regarding fire suppression resources, we used the number of terrestrial and aerial means used per fires $\geq 50$ ha, and expressed them relative to 100 ha burned. Then we aggregated data to calculate annually the mean number of resources invested per 100 ha burned.

\subsection{Statistical analysis}

We applied the modified Mann-Kendall trend test $(p<0.05)$ to analyze temporal changes in fire metrics and fire risk factors, using the R package "fume" (Bedia et al. 2012). This test is more restrictive than the Mann-Kendall test, accounting for the effective sample size and temporal autocorrelation in data (Hamed and Rao 1998). We analyzed the main breakpoints in the time series using the non-parametric Pettitt test (Pettitt 1979) using the R package "trend" (Pohlert 2016).

Finally, we evaluated if, at the provincial level, fire variables among them and in relation to fire risk factors and firefighting resources showed the same trends (negative, positive, or no trend). We used Fisher's exact test to test the association between categorical variables with small sample size. We confronted the type of trends obtained for each variable two by two, to examine the significance of their association (contingency).

\section{Results}

\subsection{Trends in fire activity}

In the 34-year period of study, fires affected a large portion of Spain, being more abundant in the northwest, Atlantic north coast, the central mountains, western areas near Portugal, and Mediterranean coast (Fig. 1). At the country level (i.e., aggregating all fires), no trend was found for the number of fires, whereas total burned area significantly decreased a Number of fires

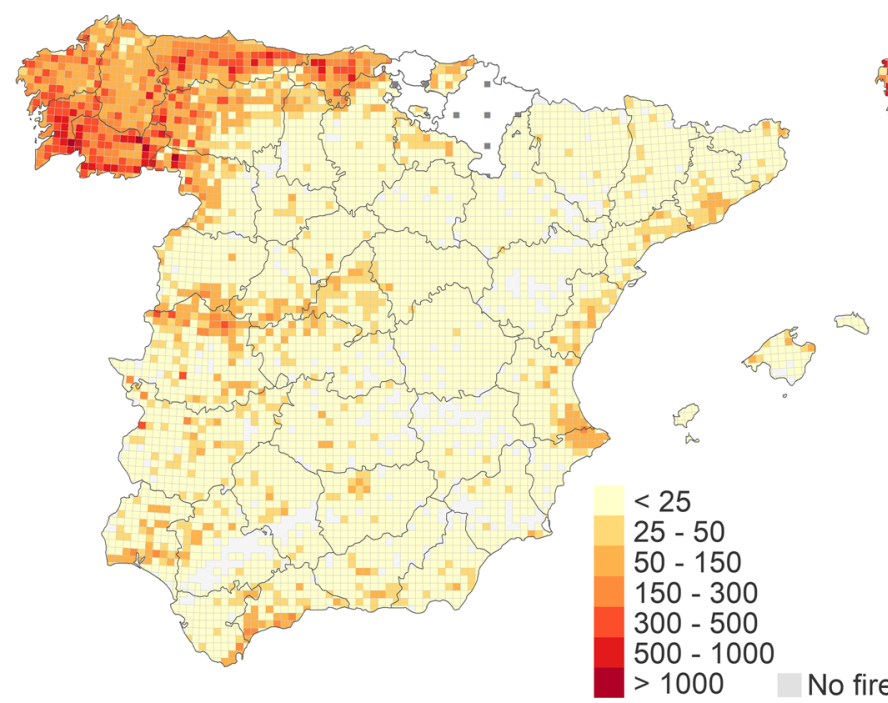

b Burned area

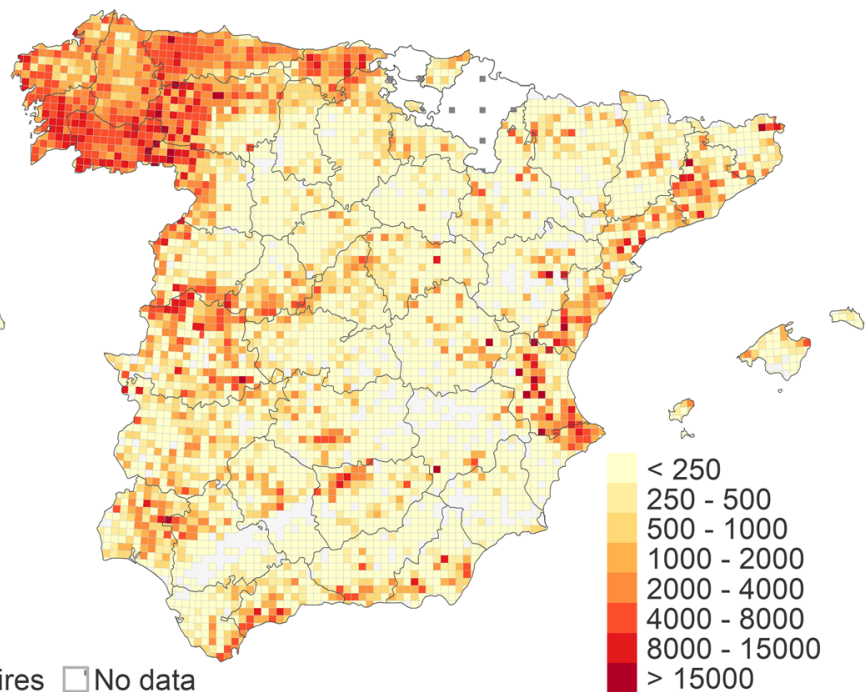

Fig. 1 a Total number of fires and $\mathbf{b}$ total burned area (ha) per $10 \times 10 \mathrm{~km}$ grid cell accumulated for 1980-2013 in Peninsular Spain and the Balearic Islands. For trend analysis, data were aggregated at the provincial (gray polygons) and country level 

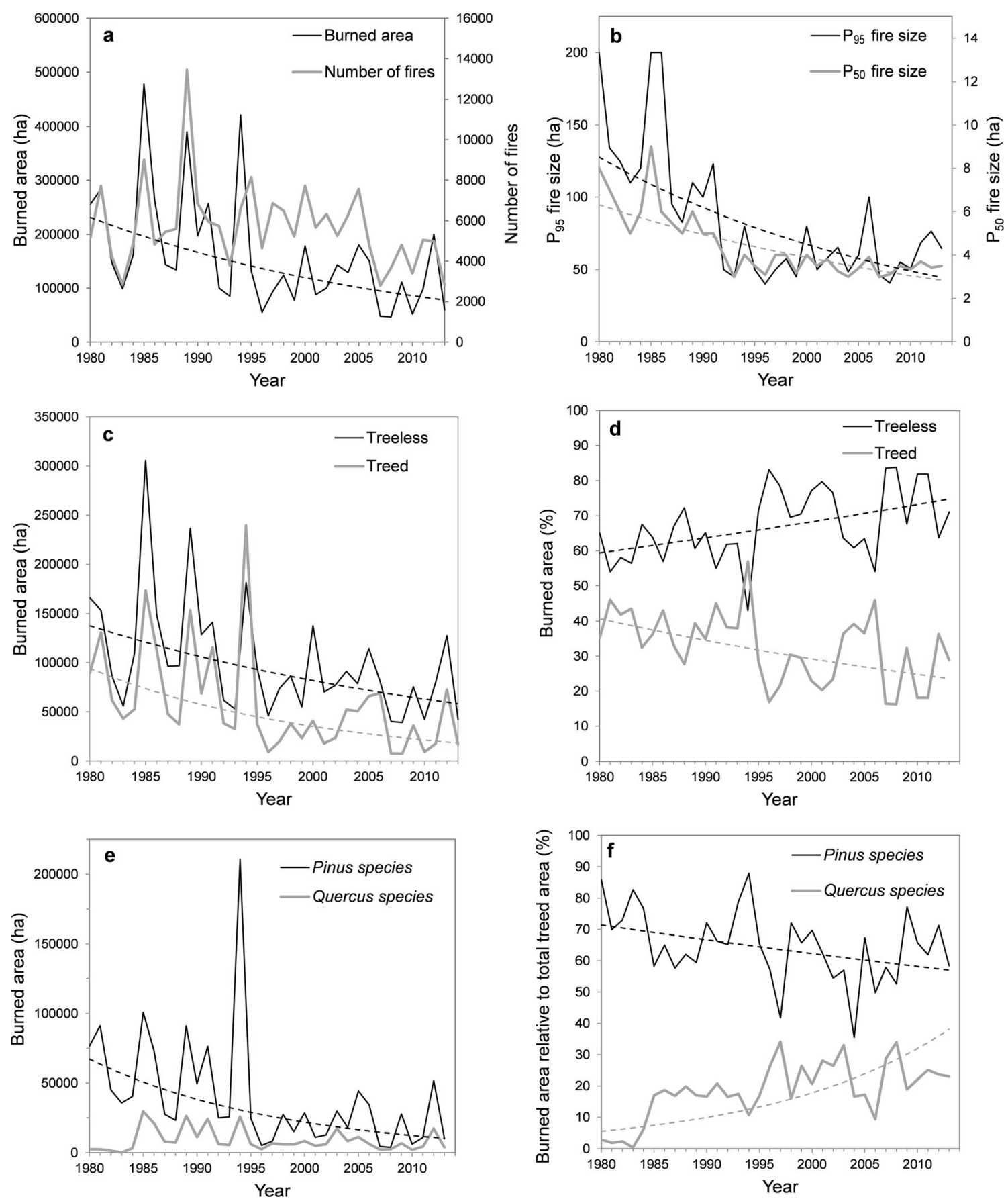

Fig. 2 Fire data annual series for Peninsular Spain and the Balearic Islands (1980-2013). a Number of fires and total burned area (ha). b $\mathrm{P}_{50}$ and $\mathrm{P}_{95}$ of fire size (ha). c Treed and treeless burned area (ha). d Treed and treeless burned area (\%). e Burned area (ha) of Pinus species

and Quercus species. f Pinus and Quercus burned area (\%) relative to total treed burned area. A loess smoothing line is shown for significant trends $(p<0.05)$

(tau $=-0.35$ ), with a breakpoint in 1994 (Fig. 2a). Significant decreasing trends were detected for both $\mathrm{P}_{50}(\operatorname{tau}=-0.58)$ and $\mathrm{P}_{95}(\mathrm{tau}=-0.41)$ of fire size, with breakpoints in 1991 and 1992, respectively (Fig. 2b). The type of burned area also decreased for both treed and treeless areas $(\operatorname{tau}=-0.35)$,

particularly after 1991 (Fig. 2c). However, the percentage of what was burned by fires increased for treeless areas $(\operatorname{tau}=0.32)$ and decreased $(\operatorname{tau}=-0.32)$ for treed ones since 1994 (Fig. 2d). Total burned area (ha) of all Pinus species decreased (tau $=-0.39$ ), with no trend for Quercus species 
a Number of fires

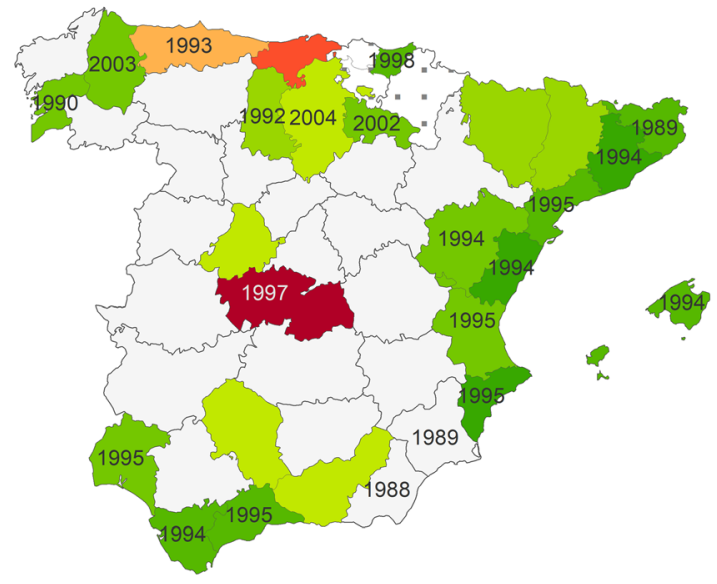

c $\mathrm{P}_{50}$ fire size

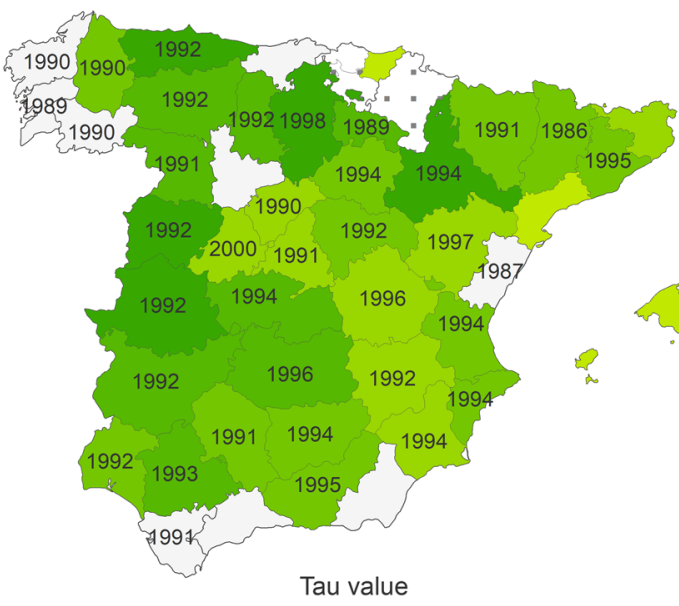

Negative trend

$\begin{array}{lll}-0.7 & -0.5 & -0.2\end{array}$ d $\mathrm{P}_{95}$ fire size

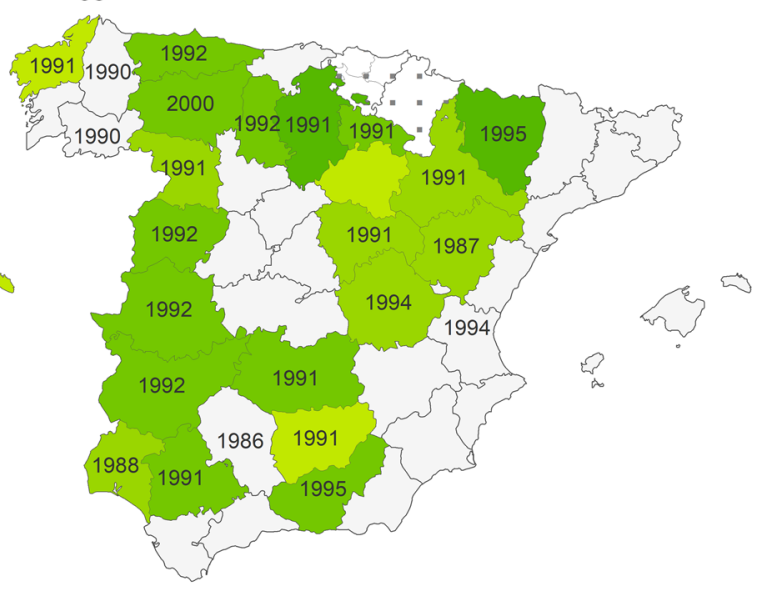

Positive trend $\square$ No trend $\square$ No data 0.6

green, positive trends in red, and gray no significant trends in the data series $(p<0.05)$. Numbers within each province indicate the breakpoint year in the data series for the corresponding variable

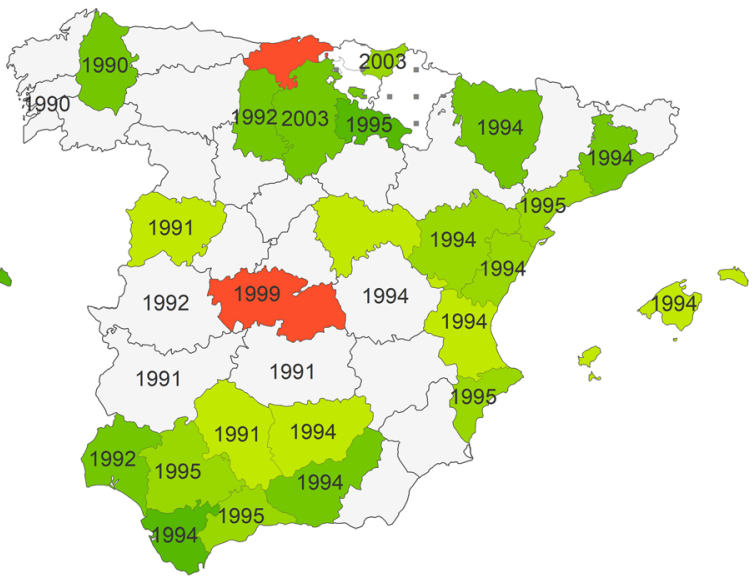

\section{b Burned area \\ bsh area}

Fig. 3 Fire data trends at provincial level (1980-2013). a Number of fires. b Total burned area (ha). $\mathbf{c} \mathrm{P}_{50}$ of fire size (ha). $\mathbf{d ~} \mathrm{P}_{95}$ of fire size (ha). Legend represents modified Mann-Kendall's Tau coefficient with negative trends in a Treed burned area

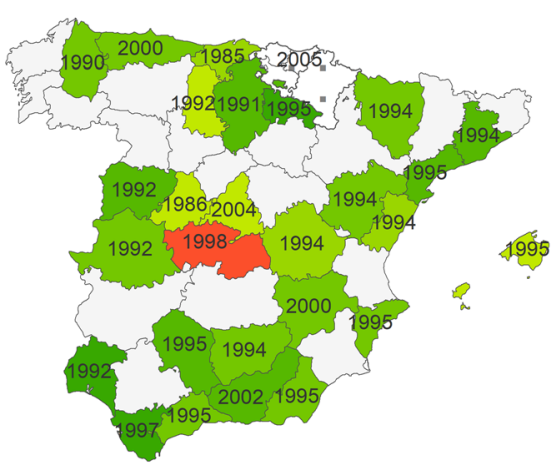

Tau value

$$
\begin{array}{lll} 
& & \text { Negative trend } \\
-0.7 & -0.5 & -0.2
\end{array}
$$

b Treeless burned area

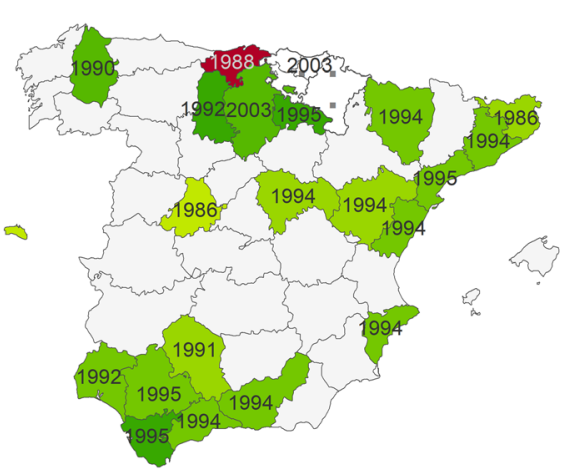

$0.2 \quad 0.30$

Fig. 4 Trends at provincial level (1980-2013). Burned area (ha) of a treed and $\mathbf{b}$ treeless areas; $\mathbf{c}$ Ratio of treeless burned area relative to the treed burned area. Legend represents modified Mann-Kendall's Tau coefficient with negative trends in green, positive trends in red, and gray no
Positive trend

\section{Ratio treeless/treed}

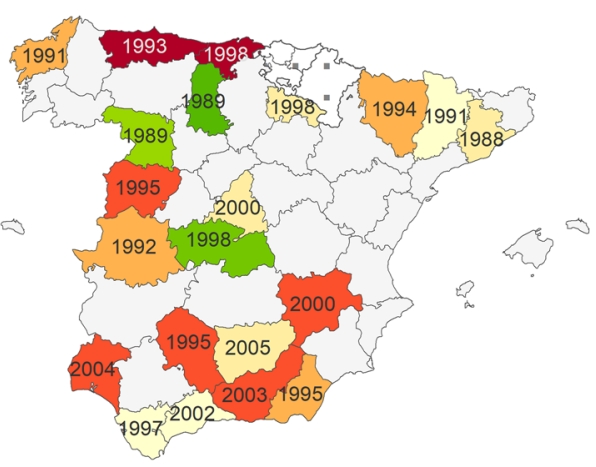

0.6

significant trends in the data series $(p<0.05)$. Numbers within each province indicate the breakpoint year in the data series for the corresponding variable 
Table 1 Trend analysis results for the burned area of all tree species by province (1980-2013). First column denotes the number of provinces where each species was present according to the EGIF database. Second and third columns denote the number of provinces with significant $(p<0.05)$ positive and negative trends for the burned area of each species, respectively

\begin{tabular}{|c|c|c|c|}
\hline Species & Provinces & + Trend & - Trend \\
\hline Abies alba Mill. & 10 & & \\
\hline Abies pinsapo Boiss. & 3 & & \\
\hline Acer sp. & 8 & & \\
\hline Alnus glutinosa (L.) Gaertn. & 26 & 1 & \\
\hline Betula sp. & 18 & 4 & \\
\hline Castanea sativa Mill. & 24 & & 3 \\
\hline Chamaecyparis lawsoniana (A.Murray bis) Parl. & 1 & & \\
\hline Corylus avellana $\mathrm{L}$. & 6 & 2 & \\
\hline Cupressus sp. & 31 & & \\
\hline Erica arborea canaria & 1 & & \\
\hline Eucalyptus camaldulensis Dehnh. & 20 & & 2 \\
\hline Eucalyptus dalrympleana Maiden & 2 & & \\
\hline Eucalyptus globulus Labill. & 22 & 2 & 1 \\
\hline Eucalyptus nittens Maiden & 6 & & \\
\hline Other Eucalyptus & 22 & 1 & \\
\hline Fagus sylvatica L. & 19 & 1 & 2 \\
\hline Fraxinus sp. & 34 & 3 & \\
\hline Ilex aquifolium $\mathrm{L}$. & 4 & 2 & \\
\hline Juglans regia $\mathrm{L}$. & 23 & & \\
\hline Juniperus oxycedrus L. & 25 & & \\
\hline Larix sp. & 4 & & \\
\hline Olea europaea $\mathrm{L}$. & 25 & 1 & 1 \\
\hline Phoenix dactyliphera $\mathrm{L}$. & 2 & & \\
\hline Picea excelsa Link & 3 & & \\
\hline Pinus canariensis C.Sm. ex DC. & 12 & & \\
\hline Pinus halepensis Mill. & 41 & 1 & 9 \\
\hline Pinus nigra Aiton & 41 & 1 & 7 \\
\hline Pinus pinaster Aiton & 45 & & 20 \\
\hline Pinus pinea $\mathrm{L}$. & 42 & 4 & 8 \\
\hline Pinus radiata D.Don & 26 & 1 & 6 \\
\hline Pinus sylvestris $\mathrm{L}$. & 36 & & 15 \\
\hline Pinus uncinata Ramond ex DC. & 15 & & \\
\hline Populus alba $\mathrm{L}$. & 41 & 7 & \\
\hline Populus nigra $\mathrm{L}$. & 39 & 5 & \\
\hline Populus tremula $\mathrm{L}$. & 25 & & \\
\hline Populus canadensis Moench & 24 & 7 & \\
\hline Other Populus & 36 & & \\
\hline Pseudotsuga menziesii (Mirb.) Franco & 13 & 1 & \\
\hline Quercus faginea Lam. & 34 & 1 & \\
\hline Quercus ilex L. & 44 & 10 & 1 \\
\hline Quercus petraea [Matt.] Liebl. & 22 & & 2 \\
\hline Quercus pyrenaica Will. & 34 & 5 & 2 \\
\hline Quercus robur L. & 28 & 2 & \\
\hline Quercus rubra $\mathrm{L}$. & 9 & 1 & \\
\hline Quercus suber L. & 30 & & \\
\hline Other Quercus & 38 & 1 & \\
\hline Salix sp. & 34 & 6 & \\
\hline Sorbus sp. & 8 & & \\
\hline Tilia sp. & 2 & & \\
\hline Ulmus sp. & 28 & 2 & \\
\hline Other conifer species & 30 & & \\
\hline Other broad-leaved species & 39 & 2 & \\
\hline
\end{tabular}

(Fig. 2e). Moreover, the percentage of burned area for Pinus decreased ( $\operatorname{tau}=-0.25)$, while that of Quercus increased (tau $=0.43)$ (Fig. 2f).

At the provincial level, either the number of fires or burned area showed no trend in almost half of the Spanish provinces (Fig. 3a, b). However, some negative trends were detected, particularly in areas with historically high fire occurrence: some provinces in the northwest (Galicia), Mediterranean (Cataluña, Valencia), and south (Andalucía). Conversely, three provinces showed positive trends: two at the north coast (Asturias, Cantabria), and one at the center (Toledo). Eighty percent of the provinces showed negative trends for $\mathrm{P}_{50}$ of fire size (Fig. 3c). However, for large fire sizes $\left(\mathrm{P}_{95}\right), 47 \%$ of the provinces showed negative trends and the rest of the 
provinces, particularly those with historically high fire occurrence, had no trend (Fig. 3d). Most of the breakpoints found in the fire variables corresponded to the 1990-1995 period.

Regarding the type of burned area, about half of the provinces showed negative trends for treed burned area (ha) (57\% of the provinces), and treeless burned area (ha) (44\% of the provinces) (Fig. 4a, b), with no significant trends in the rest. However, the proportion (\%) of treeless burned area relative to treed burned area showed positive trends in $40 \%$ of the provinces (Fig. 4c). We did not find significant trends for most of the more flammable species (e.g., Eucalyptus sp.), except for Pinus (see Table 1 for the analysis of all tree species). Pinus species showed negative trends in many of the provinces in which species were present: $P$. sylvestris (in $42 \%$ of provinces), P. pinaster (44\%), P. radiata (23\%), P. halepensis (22\%), P. pinea (19\%), and P. nigra (17\%) (Fig. 5a). Only $P$. pinea showed also an increase in the burned area in $10 \%$ of the provinces. Conversely, most Quercus species showed no trend in burned areas. Nonetheless, two oaks showed positive trends, i.e., have been increasingly more affected by fires: Q. ilex (23\% of provinces) and Q. pyrenaica $(15 \%)$, in the north and northwest of the country (Fig. 5b).

\subsection{Trends in fire risk factors and fire suppression resources}

At the country level, summer FWI values (mean and $\mathrm{P}_{95}$ ) showed a significant increase (tau $=0.34$ ), with a breakpoint in 1997 (Fig. 6a). Regarding LULC changes, agricultural areas have decreased, while forest and artificial areas have increased, particularly from 2000 to 2012 (Fig. 6b). In relation to fire suppression resources, both the number of terrestrial $(\operatorname{tau}=0.22)$ and, particularly, aerial $(\operatorname{tau}=0.80)$ resources have increased (Fig. 6c).

At the provincial level, mean summer FWI has increased in $58 \%$ of the provinces (Fig. 7a), particularly in the center, east, and south, showing a very similar pattern for extreme $\mathrm{P}_{95}$ FWI (Fig. 7b). Most of the breakpoints found in the FWI corresponded to the 1992-1998 period. According to CLC level 1, forest and semi natural areas increased in $75 \%$ of the provinces (Fig. 7c), while agricultural areas decreased in most provinces (82\%) (Fig. $7 d$ ), except in the southwestern provinces, which showed the opposite trend (i.e., increment of agricultural areas at the expense of forests). An increment of artificial areas a Pinus species
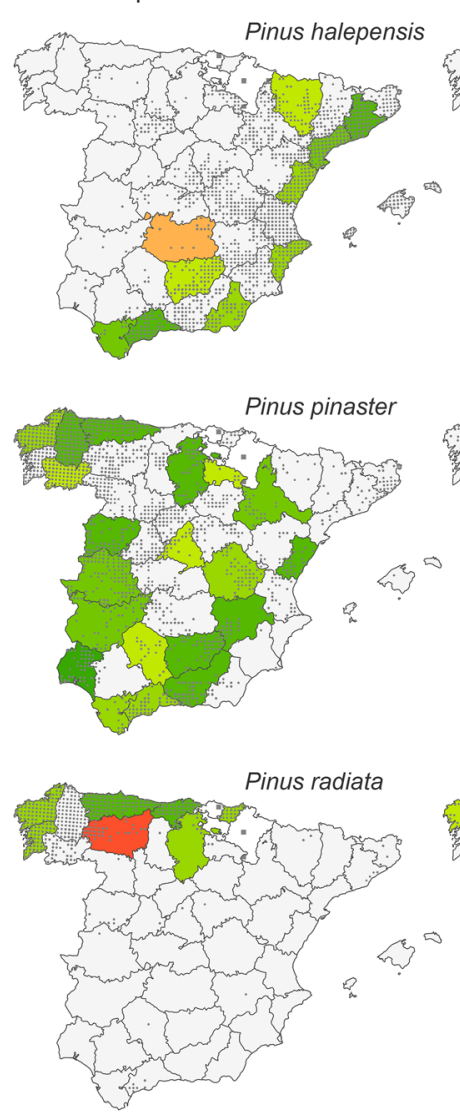
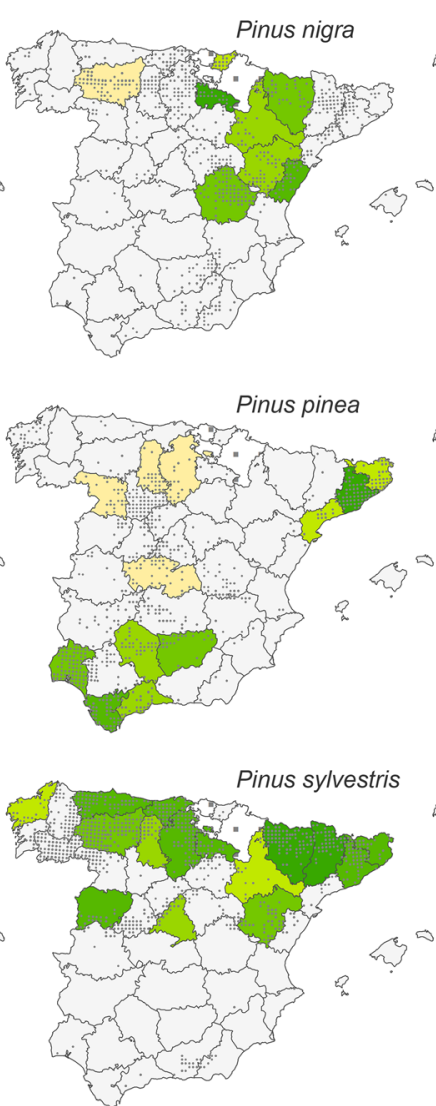

Tau value

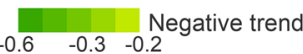

b Quercus species
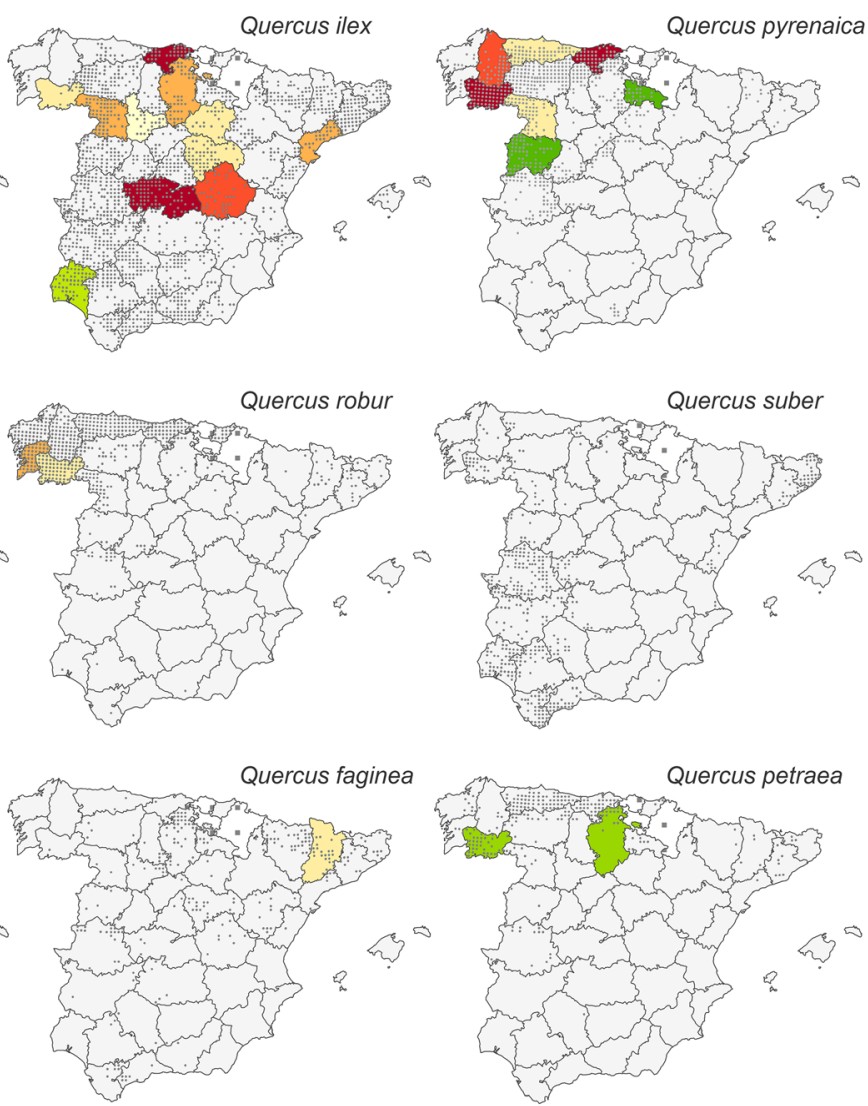

$0.20 .30 \quad$ Positive trend

No trend

Fig. 5 Trends of burned area (1980-2013) by province for a Pinus species (left maps), and b Quercus species (right maps). Legend represents modified Mann-Kendall's Tau coefficient. Dots indicate the presence of each species according to EGIF fire database 
Fig. 6 Trends of fire risk factors for Peninsular Spain and the Balearic Islands (1980-2013). a Summer (JJAS) mean FWI and $\mathrm{P}_{95}$ FWI. b LULC changes (\%) based on CORINE Land Cover (CLC) maps for forest and semi natural, agricultural, and artificial areas. c Average number of terrestrial and aerial fire suppression resources invested per 100 ha burned for fires $\geq 50$ ha. A loess smoothing line is shown for significant trends $(p<0.05)$
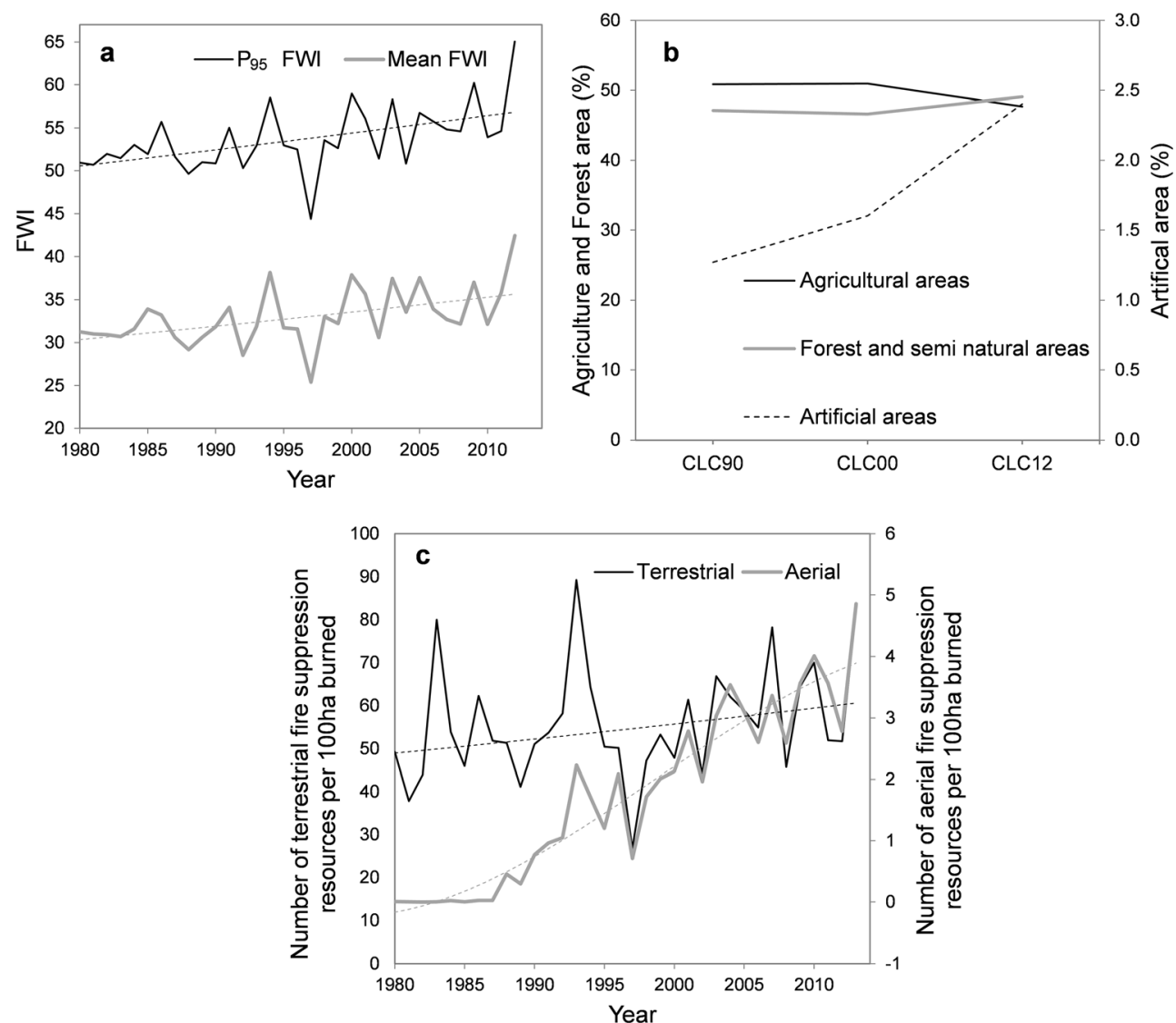

occurred in all provinces (Fig. 7e). CLC level 2 showed that, within forests and semi natural areas, treed areas increased in most provinces (84\%), while the overall extension of shrubs and herbaceous vegetation decreased (67\% of the provinces) (Fig. 8, maps not shown). At CLC level 3, broad-leaved forests increased more (in $84 \%$ of provinces) than coniferous and mixed forests (c.a. 50\%) (Fig. 8). Finally, regarding fire suppression resources, aerial means clearly increased in all provinces (Fig. 7f), while terrestrial resources increased in $40 \%$ of them (map not shown).

\subsection{Association between trends in fire activity, fire risk factors, and fire suppression}

At the provincial level, we observed that most fire variables showed negative trends (i.e., reduced fire activity) or no trend, while fire risk factors showed positive trends, except for agricultural areas that mostly decreased (Fig. 8). Based on the Fisher's exact test, we found the following significant $(p<0.05)$ associations in trends between variables (Fig. 8): (i) the number of fires increased, decreased, or did not change in the same provinces than total burned area and treed burned area (see Figs. 3a, b and 4a); ii) total burned area followed a similar pattern to the trends of treed and treeless burned areas (see Figs. 3b and 4a, b); (iii) treed burned area showed a negative association with the ratio of treeless/treed burned area: provinces that decreased their treed burned area increased the proportion of treeless burned area (see Fig. 4a, c); (iv) the ratio treeless/treed burned area showed a negative association with forest change (CLC level 1) (see Figs. $4 \mathrm{c}$ and $7 \mathrm{c}$ ); (v) mean FWI and $\mathrm{P}_{95}$ FWI showed a positive association (see Fig. 7a, b); and (vi) forest and agricultural changes showed a negative association in their trends: provinces that increased their forest area decreased their agricultural one, and vice versa (see Fig. 7c, d).

\section{Discussion}

During the last decades, fire activity in Spain has declined at the country and provincial level, despite the increase in fire risk factors. Average and extreme summer FWI conditions have increased during this period, reflecting observed regional climate change (EEA 2017). Additionally, forest and semi natural areas, together with artificial uses, have expanded at the expense of agricultural lands. However, no clear relationships were found between fire risk factors and actual fire 
a Mean FWI

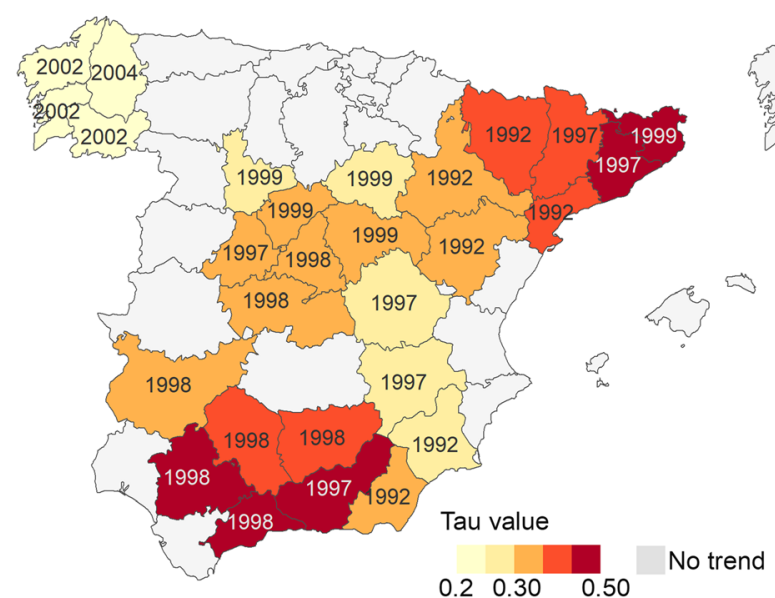

c Forest and semi natural areas

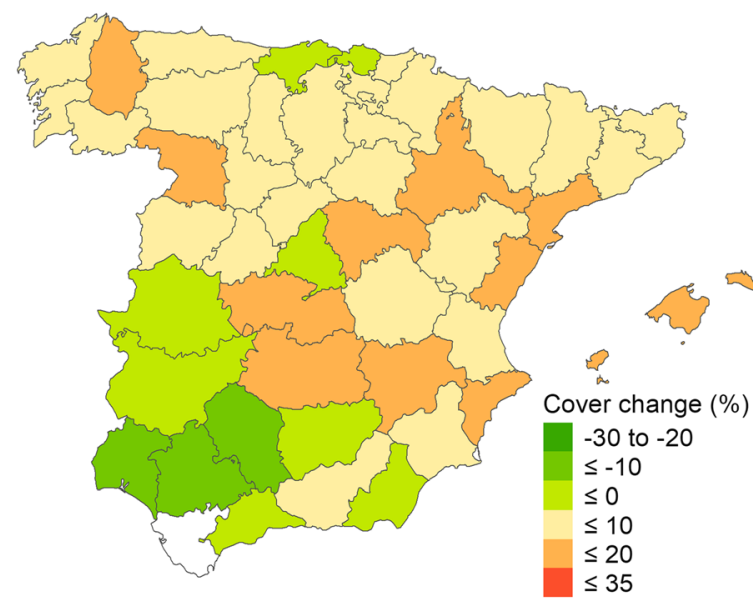

b $\mathrm{P}_{95} \mathrm{FWl}$

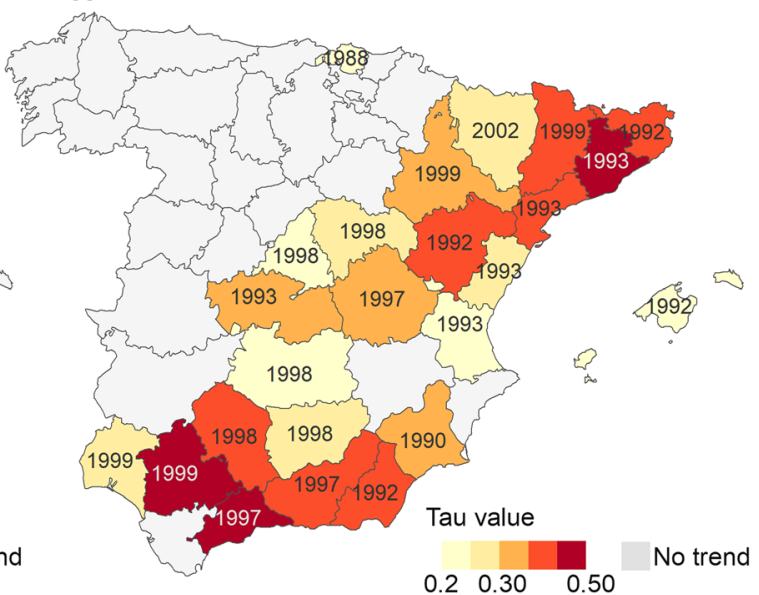

d Agricultural areas

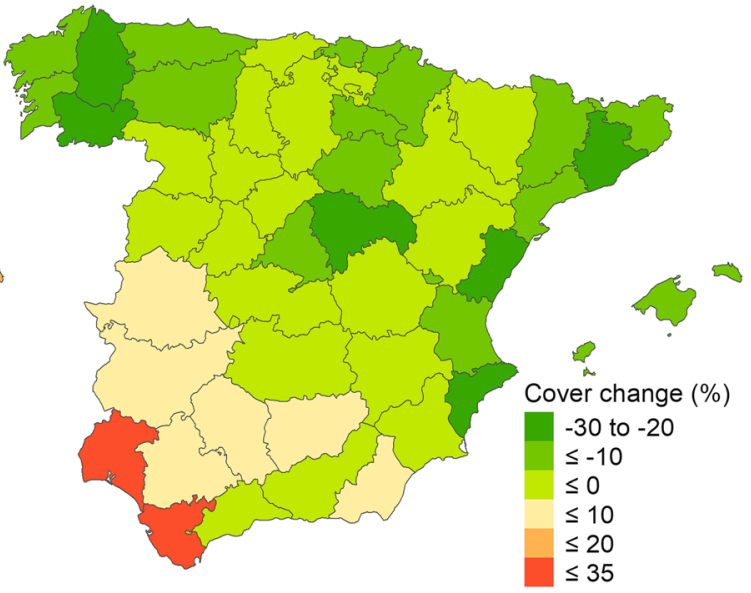

f Aerial suppression resources

e Artificial areas

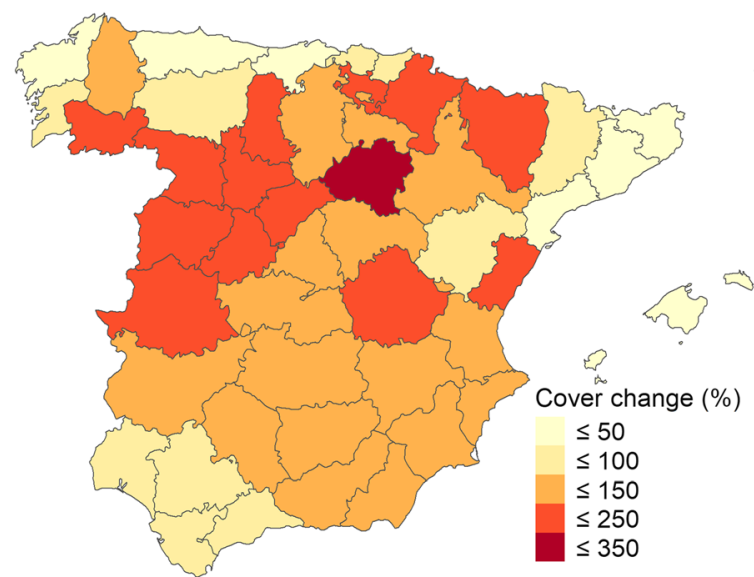

Fig. 7 Trends of fire risk factors by province (1980-2013). a Summer (JJAS) mean FWI. b P 95 FWI; LULC changes (\%) from CORINE Land Cover (CLC) maps of 1990-2012 for $\mathbf{c}$ forest and semi natural, d

trends, indicating that trends in fire activity were decoupled from trends in climate and LULC.

Decreasing trends in the number of fires and burned area were significant in provinces with historically high fire occurrence (except for the northwest [Galicia]) (see Chas-Amil

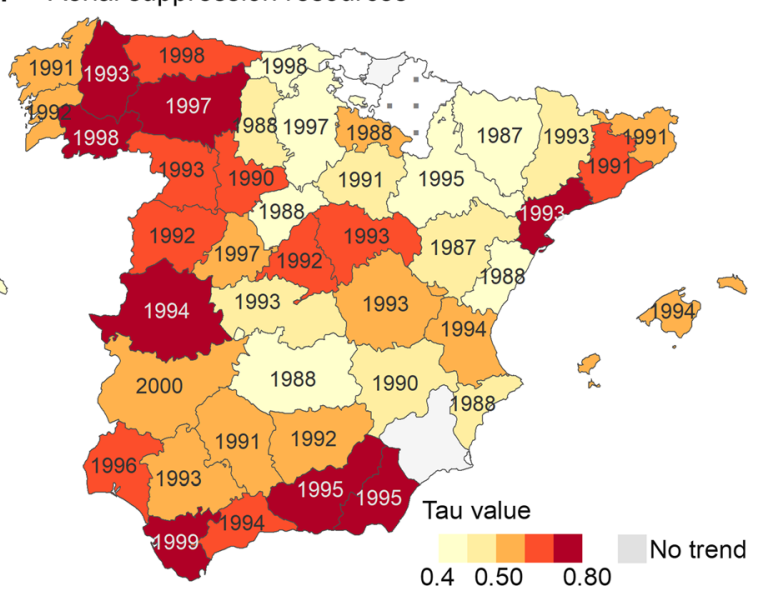

agricultural, and e artificial areas. $\mathbf{f}$ Average number of aerial suppression resources used per 100 ha burned. Numbers within each province indicate the breakpoint year in the data series for the corresponding variable

et al. 2015), suggesting that fire suppression efforts might have been more effective in these areas, particularly after the 1990-1995 peak fires (e.g., Moreno et al. 2014). Three provinces showed positive trends in the number of fires or burned area, and two of them (in the north coast) were the ones with 


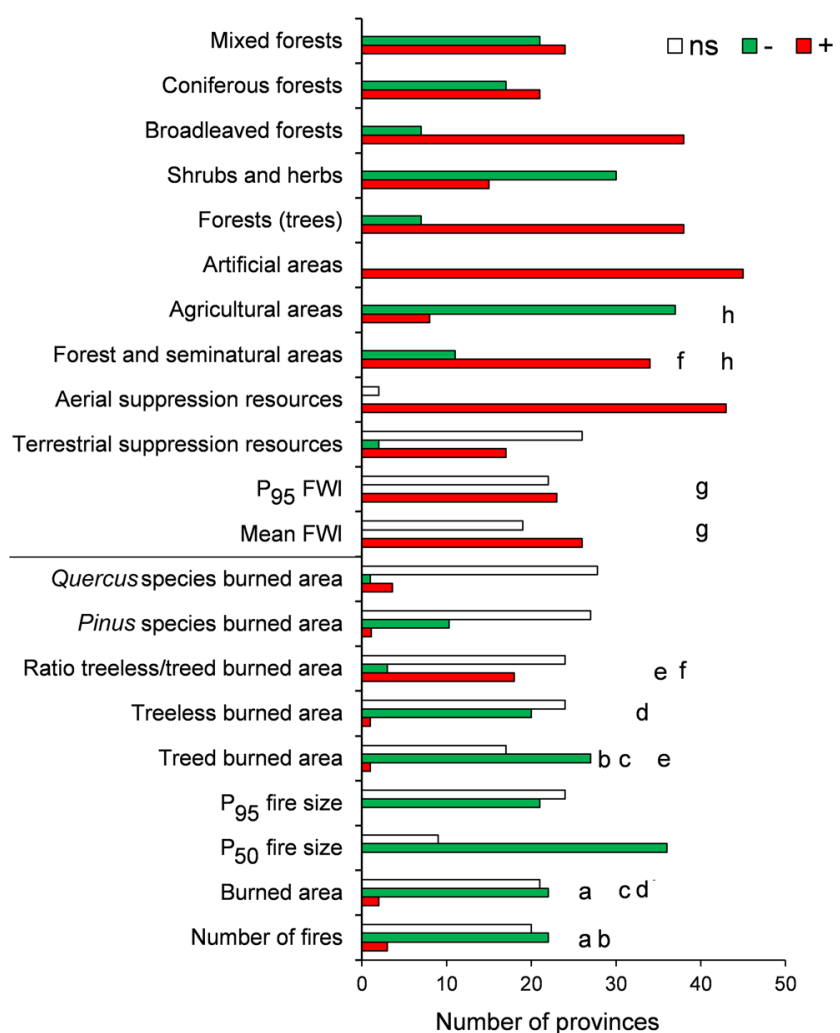

Fig. 8 Number of provinces showing the different types of trends (positive (red), negative (green), or non-significant (blank)) for each fire variable, fire risk factor, and fire suppression resources. The upper eight variables correspond to CORINE data and they represent change in time (negative or positive) but not trends. Variables sharing the same letter indicate that they were significantly associated according to a contingency Fisher's exact test

the lowest figures in suppression resources per fire (Costafreda-Aumedes et al. 2016). Not only fire activity decreased, but also fire size patterns changed. The median $\left(\mathrm{P}_{50}\right)$ and extreme $\left(\mathrm{P}_{95}\right)$ fire size tended to show a negative trend, i.e., towards smaller size. The major transition points were located in the first half of 1990s, when the greatest large fire episode occurred in Spain (Moreno et al. 1998). Nonetheless, provinces with historically high fire occurrence showed no significant trends in $\mathrm{P}_{95}$ fire size, indicating that inter-annual variability is high, and peaks of large fires occur. This suggests that fire suppression can reduce or stabilize fire activity (e.g., Moreno et al. 2014; Fréjaville and Curt 2017), but could affect less the incidence of large fires driven by extreme weather (e.g., Fernandes et al. 2016).

Landscapes became more hazardous with time, since land abandonment led to an increase in forest area. Treeless areas burned proportionally more than treed ones in many provinces. Fires in southern Europe have more preference for shrublands than for flammable forest types (Moreira et al. 2009; Oliveira et al. 2014), but may vary among locations (Moreno et al. 2011). This could be due to a change in the ignition patterns owing to shifts in the wildland-agricultural and wildland-urban interfaces (Rodrigues et al. 2014; Modugno et al. 2016). Ortega et al. (2012) found that the most vulnerable landscapes were those with a high diversity of land uses, with forest-agriculture mixtures. Similarly, Viedma et al. (2018) showed that, in central Spain, fires lost the links with the initial fire-prone areas (conifers), and became more associated with lower altitude and less forested (treeless) areas. Nonetheless, land cover and forest type may not totally align with fuels and overall fire hazard. Forest composition can account for a small variation in fuel loading and other fuel characteristics (Fernandes et al. 2019).

Fire trends could also be affected by changes in the cause of ignition. In Spain (and in EUMed), a minor percentage of fires are caused by lightning, and most are caused by people. Fires of these two sources tend to occur at different locations (Vázquez and Moreno 1998), which could affect the vegetation they burn and the difficulty of extinction. However, no changes between these two sources have been observed (Ganteaume et al. 2013). Regarding people-caused fires, the majority of them are voluntary, followed by negligence. In recent times, negligence fires are increasing and voluntary ones decreasing (Ganteaume et al. 2013). Whether this is differentially affecting the fire trends, by way of the vegetation they burn or the point of ignition, is something that needs research.

Flammable species, like most Pinus, were expected to be positively related to fire activity, since large and high-severity fires have been associated with these species, whereas broadleaved forests showed negative selectivity and lower severity (e.g., Fernandes et al. 2010; Moreno et al. 2011; Barros and Pereira 2014). Our results, however, showed that trends in burned areas of Pinus species were mostly negative. In contrast, species less flammable, like Quercus, notably the deciduous ones, were expected to not have a trend, which was generally true. However, species like $Q$. ilex and Q. pyrenaica are burning increasingly more frequently in the center and northwest of their distributions. A significant positive relationship between forest fires and the afforested areas has been found in Spain, especially 30-35 years after plantations (Iriarte-Goñi and Ayuda 2018). However, conifer plantations have been reduced in the last decades, as attested by CORINE data. This could be due to a change in ignition patterns (e.g., Viedma et al. 2018), or to the leverage of previous burning (Price et al. 2015). In contrast, broad-leaved forests, mostly Quercus, are increasing according to CORINE, as a likely reflection of abandonments. Abandonment of grazing of old dehesas (open oak woodlands with pastures) might have led to encroachment by shrubs, hence facilitating ignitions and fire spread (Torres et al. 2012; Salis et al. 2019). Moreover, Quercus species are invading many pines stands (Urbieta et al. 2011), and when burned, these may turn into oak forests (Torres et al. 2016). Recurrent fires could have more negatively affected pines (seeders) than oaks 
(resprouters). For example, $P$. nigra, $P$. sylvestris, and $P$. pinea (seeders that produce few seedlings) usually change to other vegetation types after high-severity fires without proper management to reestablish them back (Rodrigo et al. 2004). Moreover, $P$. halepensis and $P$. pinaster forests have very low resilience when burned frequently, and may turn into shrublands (e.g., Viedma et al. 2006; González-De Vega et al. 2016).

\section{Conclusion}

Wildfires in Spain are decreasing in number, burned area, mean fire size and, in most provinces, also in the largest fire size. Wildfires are burning preferentially treeless than treed areas. Moreover, Pinus forests are burning less, while Quercus forests are burning more. This has occurred despite that fire risk factors have been rising: weather conditions became more severe, and landscapes more hazardous, owing to greater forest cover. Decreasing fire activity can largely be justified by the increase in firefighting resources, particularly aerial ones, which showed positive trends.

Acknowledgments We thank ADCIF (Área de Defensa contra Incendios Forestales) from the Spanish Ministry of Agriculture, Fisheries and Food for providing us with the Spanish National Forest Fire Statistics (EGIF).

Funding The research has received funding from FOCCLIM project (CGL2016-78357-R), funded by the Spanish Ministerio de Economía y Competitividad, and INFOADAPT (FB-2014-CC-INFOADAPT), funded by Fundación Biodiversidad.

Data availability The datasets analyzed during the current study are available from the corresponding author on reasonable request. The data can be requested from the following sources: Spanish National Forest Fire Statistics (EGIF) from the Spanish Ministry of Agriculture, Fisheries and Food; Daily meteorological data from the reanalysis of WFDEI (WATCH-Forcing-Data- 111 ERA-Interim) (Weedon et al. 2014); LULC data from CORINE Land Cover Project at https://land. copernicus.eu/pan-european/corine-land-cover.

\section{Compliance with ethical standards}

Conflicts of interest The authors declare that they have no conflict of interest.

\section{References}

Andela N, Morton DC, Giglio L, Chen Y, van der Werf GR, Kasibhatla PS, DeFries RS, Collatz GJ, Hantson S, Kloster S, Bachelet D, Forrest M, Lasslop G, Li F, Mangeon S, Melton JR, Yue C, Randerson JT (2017) A human-driven decline in global burned area. Science 356:1356-1362. https://doi.org/10.1126/science.aal4108

Barros AMG, Pereira JMC (2014) Wildfire selectivity for land cover type: does size matter? PLoS One 9:e84760. https://doi.org/10. 1371/journal.pone. 0084760
Bedia J, Herrera S, Gutiérrez JM, Zavala G, Urbieta IR, Moreno JM (2012) Sensitivity of fire weather index to different reanalysis products in the Iberian Peninsula. Nat Hazard Earth Sys 12:699-708. https://doi.org/10.5194/nhess-12-699-2012

Bedia J, Herrera S, Camia A, Moreno JM, Gutiérrez JM (2014) Forest fire danger projections in the Mediterranean using ENSEMBLES regional climate change scenarios. Clim Chang 122:185-199. https://doi.org/10.1007/s10584-013-1005-z

Benali A, Mota B, Carvalhais N, Oom D, Miller LM, Campagnolo ML, Pereira JMC (2017) Bimodal fire regimes unveil a global-scale anthropogenic fingerprint. Glob Ecol Biogeogr 26:799-811. https:// doi.org/10.1111/geb.12586

Bowman DMJS, Williamson GJ, Abatzoglou JT, Kolden CA, Cochrane MA, Smith AMS (2017) Human exposure and sensitivity to globally extreme wildfire events. Nat Ecol Evol 1:0058. https://oi.org/ 10.1038/s41559-016-0058

Brotons L, Aquilué N, de Cáceres M, Fortin MJ, Fall A (2013) How fire history, fire suppression practices and climate change affect wildfire regimes in Mediterranean landscapes. PLoS One 8:e62392. https:// doi.org/10.1371/journal.pone.0062392

Chas-Amil ML, Prestemon JP, McClean CJ, Touza J (2015) Humanignited wildfire patterns and responses to policy shifts. Appl Geogr 56:164-176. https://doi.org/10.1016/j.apgeog.2014.11.025

Costafreda-Aumedes S, Cardil A, Molina DM, Daniel SN, Mavsar R, Vega-Garcia C (2016) Analysis of factors influencing deployment of fire suppression resources in Spain using artificial neural networks. iForest 9:138-145. https://doi.org/10.3832/ifor1329-008

Earl N, Simmonds I (2018) Spatial and temporal variability and trends in 2001-2016 global fire activity. J Geophys Res Atmos 123:25242536. https://doi.org/10.1002/2017JD027749

EEA (European Environment Agency) (2017) Climate change, impacts and vulnerability in Europe 2016 - An indicator based report. EEA Report No. 1/2017. Luxemburg. https://doi.org/10.2800/534806

Fernandes PM, Luz A, Loureiro C (2010) Changes in wildfire severity from maritime pine woodland to contiguous forest types in the mountains of northwestern Portugal. For Ecol Manag 260:883892. https://doi.org/10.1016/j.foreco.2010.06.008

Fernandes PM, Loureiro C, Guiomar N, Pezzatti GB, Manso FT, Lopes L (2014) The dynamics and drivers of fuel and fire in the Portuguese public forest. J Environ Manag 146:373-382. https://doi.org/10. 1016/j.jenvman.2014.07.049

Fernandes PM, Barros AMG, Pinto A, Santos JA (2016) Characteristics and controls of extremely large wildfires in the western Mediterranean Basin. J Geophys Res Biogeosci 121:2141-2157. https://doi.org/10.1002/2016jg003389

Fernandes PM, Guiomar N, Rossa CG (2019) Analysing eucalypt expansion in Portugal as a fire-regime modifier. Sci Total Environ 666:7988. https://doi.org/10.1007/s10342-019-01179-1

Fréjaville T, Curt T (2017) Seasonal changes in the human alteration of fire regimes beyond the climate forcing. Environ Res Lett 12:35006. https://doi.org/10.1088/1748-9326/aa5d23

Ganteaume A, Camia A, Jappiot M, San-Miguel-Ayanz J, Long-Fournel M, Lampin C (2013) A review of the main driving factors of forest fire ignition over Europe. Environ Manag 51:651-662. https://doi. org/10.1007/s00267-012-9961-z

Gómez-González S, Ojeda F, Fernandes PM (2018) Portugal and Chile: longing for sustainable forestry while rising from the ashes. Environ Sci Pol 81:104-107. https://doi.org/10.1016/j.envsci.2017.11.006

González-De Vega S, De las Heras J, Moya D (2016) Resilience of Mediterranean terrestrial ecosystems and fire severity in semiarid areas: responses of Aleppo pine forests in the short, mid and long term. Sci Total Environ 573:1171-1177. https://doi.org/10.1016/j. scitotenv.2016.03.115

Gudmundsson L, Rego FC, Rocha M, Seneviratne SI (2014) Predicting above normal wildfire activity in southern Europe as a function of 
meteorological drought. Environ Res Lett 9:84008. https://doi.org/ 10.1088/1748-9326/9/8/084008

Hamed KH, Rao AR (1998) A modified Mann-Kendall trend test for autocorrelated data. J Hydrol 204:182-196. https://doi.org/10. 1016/S0022-1694(97)00125-X

Heymann Y, Steenmans C, Croissille G, Bossard M (1994) Corine land cover- a technical guide. Office for Official Publications of European Communities. CEC, Luxembourg http://www.eea. europa.eu/publications/COR0-landcover. Accessed 24 May 2019

Iriarte-Goñi I, Ayuda M-I (2018) Should Forest Transition Theory include effects on forest fires? The case of Spain in the second half of the twentieth century. Land Use Policy 76:789-797. https://doi.org/10. 1016/j.landusepol.2018.03.009

Jolly WM, Cochrane MA, Freeborn PH, Holden ZA, Brown TJ, Williamson GJ, Bowman DMJS (2015) Climate-induced variations in global wildfire danger from 1979 to 2013. Nat Commun 6:7537. https://doi.org/10.1038/ncomms 8537

Modugno S, Balzter H, Cole B, Borrelli P (2016) Mapping regional patterns of large forest fires in Wildland-Urban Interface areas in Europe. J Environ Manag 172:112-126. https://doi.org/10.1016/j. jenvman.2016.02.013

Moreira F, Rego F, Ferreira P (2001) Temporal (1958-1995) pattern of change in a cultural landscape of northwestern Portugal: implications for fire occurrence. Landsc Ecol 2:557-567. https://doi.org/10. 1023/A:1013130528470

Moreira F, Vaz P, Catry F, Silva JS (2009) Regional variations in wildfire susceptibility of land-cover types in Portugal: implications for landscape management to minimize fire hazard. Int J Wildland Fire 18: 563-574. https://doi.org/10.1071/WF07098

Moreno JM, Vázquez A, Vélez R (1998) Recent history of forest fires in Spain. In: Moreno JM (ed) Large forest fires. Backhuys Publishers, Leiden, The Netherlands, pp 159-185

Moreno JM, Viedma O, Zavala G, Luna B (2011) Landscape variables influencing forest fires in central Spain. Int J Wildland Fire 20:678689. https://doi.org/10.1071/WF10005

Moreno MV, Conedera M, Chuvieco E, Pezzatti GB (2014) Fire regime changes and major driving forces in Spain from 1968 to 2010. Environ Sci Pol 37:11-22. https://doi.org/10.1016/j.envsci.2013. 08.005

Nunes AN, Lourenço L, Meira ACC (2016) Exploring spatial patterns and drivers of forest fires in Portugal (1980-2014). Sci Total Environ 573:1190-1202. https://doi.org/10.1016/j.scitotenv.2016.03.121

Nunes L, Álvarez-González J, Alberdi I, Silva V, Rocha M, Rego FC (2019) Analysis of the occurrence of wildfires in the Iberian Peninsula based on harmonised data from national forest inventories. Ann For Sci 76:27. https://doi.org/10.1007/s13595-019-0811-5

Oliveira S, Pereira JMC, San-Miguel-Ayanz J, Lourenço L (2014) Exploring the spatial patterns of fire density in southern Europe using geographically weighted regression. Appl Geogr 51:143157. https://doi.org/10.1016/j.apgeog.2014.04.002

Ortega M, Saura S, González-Avila S, Gómez-Sanz V, Elena-Rosselló R (2012) Landscape vulnerability to wildfires at the forest-agriculture interface: half-century patterns in Spain assessed through the SISPARES monitoring framework. Agrofor Syst 85:331-349. https://doi.org/10.1007/s10457-011-9423-2

Parisien M-A, Miller C, Parks SA, DeLancey ER, Robinne F-N, Flannigan MD (2016) The spatially varying influence of humans on fire probability in North America. Environ Res Lett 11:075005. https://doi.org/10.1088/1748-9326/11/7/075005

Pausas JG, Fernández-Muñoz S (2012) Fire regime changes in the Western Mediterranean Basin: from fuel-limited to drought-driven fire regime. Clim Chang 110:215-226. https://doi.org/10.1007/ s10584-011-0060-6

Pausas JG, Keeley JE (2009) A burning story: the role of fire in the history of life. Biosci 59:593-601. https://doi.org/10.1525/bio. 2009.59.7.10
Pettitt AN (1979) A non-parametric approach to change-point problem. Appl Stat 28:126-135. https://doi.org/10.2307/2346729

Pohlert T (2016) Trend: non-parametric trend tests and change-point detection. $\mathrm{R}$ package version 0.2 .0

Price OF, Pausas JG, Govender N, Flannigan M, Fernandes PM, Brooks ML, Bird RB (2015) Global patterns in fire leverage: the response of annual area burnt to previous fire. Int J Wildland Fire 24:297-306. https://doi.org/10.1071/WF14034

Rodrigo A, Retana J, Picó FX (2004) Direct regeneration is not the only response of mediterranean forests to large fires. Ecology 85:716729. https://doi.org/10.1890/02-0492

Rodrigues M, San-Miguel-Ayanz J, Oliveira S, Moreira F, Camia A (2013) An insight into spatial-temporal trends of fire ignitions and burned areas in the European Mediterranean countries. J Earth Sci Eng 3:497-505

Rodrigues M, de la Riva J, Fotheringham S (2014) Modeling the spatial variation of the explanatory factors of human-caused wildfires in Spain using geographically weighted logistic regression. Appl Geogr 48:52-63. https://doi.org/10.1016/j.apgeog.2014.01.011

Ruffault J, Mouillot F (2015) How a new fire-suppression policy can abruptly reshape the fire-weather relationship. Ecosphere 6:1-19. https://doi.org/10.1890/es15-00182.1

Salis M, Arca B, Alcasena-Urdiroz F, Massaiu A, Bacciu V, Bosseur F, Caramelle P, Dettori S, Fernandes de Oliveira AS, Molina-Terren D, Pellizzaro G, Santoni PA, Spano D, Vega-Garcia C, Duce P (2019) Analyzing the recent dynamics of wildland fires in Quercus suber L. woodlands in Sardinia (Italy), Corsica (France) and Catalonia (Spain). Eur J For Res 138:415-431. https://doi.org/10.1007/ s10342-019-01179-1

San-Miguel-Ayanz J, Moreno JM, Camia A (2013) Analysis of large fires in European Mediterranean landscapes: lessons learned and perspectives. For Ecol Manag 294:11-22. https://doi.org/10.1016/j.foreco. 2012.10.050

Silva JMN, Moreno MV, Le Page Y, Oom D, Bistinas I, Pereira JMC (2019) Spatiotemporal trends of area burnt in the Iberian Peninsula, 1975-2013. Reg Environ Chang 19:515-527. https://doi.org/10. 1007/s10113-018-1415-6

Syphard AD, Keeley JE, Pfaff AH, Ferschweiler K (2017) Human presence diminishes the importance of climate in driving fire activity across the United States. Proc Natl Acad Sci 114:13750-13755. https://doi.org/10.1073/pnas.1713885114

Torres I, Urbieta IR, Moreno JM (2012) Vegetation and soil seed bank relationships across microhabitats in an abandoned Quercus suber parkland under simulated fire. Écoscience 19:1-10. https://doi.org/ 10.2980/19-1-3459

Torres I, Pérez B, Quesada J, Viedma O, Moreno JM (2016) Forest shifts induced by fire and management legacies in a Pinus pinaster woodland. For Ecol Manag 361:309-317. https://doi.org/10.1016/j. foreco.2015.11.027

Turco M, Llasat MC, von Hardenberg J, Provenzale A (2014) Climate change impacts on wildfires in a Mediterranean environment. Clim Chang 125:369-380. https://doi.org/10.1007/s10584-014-1183-3

Turco M, Bedia J, Di Liberto F, Fiorucci P, Von Hardenberg J, Koutsias N, Llasat MC, Xystrakis F, Provenzale A (2016) Decreasing fires in mediterranean Europe. PLoS One 11:e15066. https://doi.org/10. 1371/journal.pone.0150663

Turco M, von Hardenberg J, AghaKouchak A, Llasat MC, Provenzale A, Trigo RM (2017) On the key role of droughts in the dynamics of summer fires in Mediterranean Europe. Sci Rep 7:81. https://doi. org/10.1038/s41598-017-00116-9

Turco M, Rosa-Cánovas JJ, Bedia J, Jerez S, Montávez JP, Llasat MC, Provenzale A (2018) Exacerbated fires in Mediterranean Europe due to anthropogenic warming projected with non-stationary climatefire models. Nat Commun 9:3821. https://doi.org/10.1038/s41467018-06358-Z 
Urbieta IR, García LV, Zavala MA, Marañón T (2011) Mediterranean pine and oak distribution in southern Spain: is there a mismatch between regeneration and adult distribution? J Veg Sci 22:18-31. https://doi.org/10.1111/j.1654-1103.2010.01222.x

Urbieta IR, Zavala G, Bedia J, Gutiérrez JM, San Miguel-Ayanz J, Camia A, Keeley JE, Moreno JM (2015) Fire activity as a function of fireweather seasonal severity and antecedent climate across spatial scales in southern Europe and Pacific western USA. Environ Res Lett 10:114013. https://doi.org/10.1088/1748-9326/10/11/114013

van Wagner CE (1987) Development and structure of the Canadian forest fire weather index system. Canadian forestry service, forestry technical report 35, Ottawa

Vázquez A, Moreno JM (1998) Patterns of lightning-, and people- caused fires in peninsular Spain. Int J Wildland Fire 8:103-115. https://doi. org/10.1071/WF9980103

Vázquez A, Climent JM, Casais L, Quintana JR (2015) Current and future estimates for the fire frequency and the fire rotation period in the main woodland types of peninsular Spain: a case-study approach. For Syst 24:e031. https://doi.org/10.5424/fs/201524206454

Venäläinen A, Korhonen N, Hyvärinen O, Koutsias N, Xystrakis F, Urbieta IR, Moreno JM (2014) Temporal variations and change in forest fire danger in Europe for 1960-2012. Nat Hazards Earth Syst Sci 14:1477-1490. https://doi.org/10.5194/nhess-14-1477-2014

Viedma O, Moreno JM, Rieiro I (2006) Interactions between land use/ land cover change, forest fires and landscape structure in Sierra de Gredos (Central Spain). Environ Conserv 33:212-222. https://doi. org/10.1017/S0376892906003122

Viedma O, Moity N, Moreno JM (2015) Changes in landscape firehazard during the second half of the 20th century: agriculture abandonment and the changing role of driving factors. Agric Ecosyst Environ 207:126-140. https://doi.org/10.1016/j.agee.2015.04.011

Viedma O, Urbieta IR, Moreno JM (2018) Wildfires and the role of their drivers are changing over time in a large rural area of west-central Spain. Sci Rep 8:17797. https://doi.org/10.1038/s41598-01836134-4

Weedon GP, Balsamo G, Bellouin N, Gomes S, Best MJ, Viterbo P (2014) The WFDEI meteorological forcing data set: WATCH forcing data methodology applied to ERA-Interim reanalysis data. Water Resour Res 50:7505-7514. https://doi.org/10.1002/2014wr015638

Publisher's note Springer Nature remains neutral with regard to jurisdictional claims in published maps and institutional affiliations. 